\title{
A SURVEY OF THE STATUTORY LAW OF INDUSTRIAL INSURANCE
}

\author{
Harry Goldstein*
}

An institution which vitally affects the vast majority of wage-earners merits study and concern. In July, I933, it is estimated, there were approximately 50,000,000 holders of Industrial policies; ${ }^{1}$ the average amount held by each person in the group was $\$ 29 \mathrm{I},{ }^{2}$ representing 5.9 per cent of their annual income. ${ }^{3}$ Despite the enormous extent of the Industrial insurance business, it has proceeded largely without detailed statutory regulation. Ordinary insurance, which involves fewer policies and policyholders and a class of policyholders better able to protect their interests, is much more stringently regulated. ${ }^{4}$ In England Industrial insurance has been the subject of special statutory regulation; ${ }^{5}$ similar legislation has been proposed for this country as a remedy for the defects in this branch of insurance. ${ }^{6}$ Before coming to any conclusions as to the desirability of legislative reform, it may be well to examine what has been done by state legislatures and Congress in the control of Industrial insurance.

The underlying factors behind the comprehensive statutory regulation of insurance may be summed up as follows: (I) The important position which insurance holds in our economic system. (2) A recognition of the fact that the insurance contract is not one where both parties bargain on an equal footing, but rather one

- A.B., 1933, Brown University. Now a member of the second year class in the Duke University School of Law.

${ }^{2}$ Sec Taylor, Social Cost of Industrial Insurance (r933) 54. Spectator Year Book of Insurance for 1929 fixes the number of Industrial policies in force at $85,384,794$.

TAYLOR, op. cit. supra note $I$, at $6 \mathrm{I}$ adopts the estimates of W. I. King as to the number of wageearners, approximately 63,000,000, in the year x 930 .

${ }^{3} I d$., at 193 . This figure is based on the estimated total income as against the premiums paid in 1932. For statistical material on the cost of Industrial insurance, see id. at 160-I99. For estimates as to the amount of Industrial insurance written, the number of policies and the amount of insurance in force each year from I876-i 924, see Ackerman, Industriaz Life Insurance (I926) 50-52.

'The Armstrong Committee's investigation of life insurance in New York in Igos did not concern itself particularly with Industrial insurance and therefore had no special recommendations to make regarding it. Subsequent insurance legislation in other states, based on the New York legislation, gave Industrial insurance very little consideration. Possible explanations for the relative dearth of legislation in the Industrial branch are suggested in Fuller, The Special Nature of the Wage-earner's Life Instrance Problems, supra at p. 44 .

${ }^{5}$ I3 \& I4 GEO. V, c. 8 (I923).

'Hearing before the Subcommittee on Instrance and Banks of the Committee on the District of Columbia on S. 1903, 71st Cong., 2d Sess. (r930) at $\mathrm{rx}$. 
where the terms of the policy are dictated by the insurer. To prevent the detrimental use of the insurer's superior bargaining power is the aim of much insurance legislation. (3) The long-term nature of the insurance contract makes desirable a constant supervision over the financial condition of the insurer so that its obligations can be paid at maturity.

State regulation of the insurance business is accomplished by administrative control. Accordingly, the typical insurance àct begins with the creation of an insurance department, followed by provision for its personnel and maintenance. The function of this department is the enforcement of insurance legislation, the exercise of a continued supervision, as limited by statute, over the insurance business. Professor Patterson in his work on the insurance commissioner has classified this legislation as follows: ${ }^{7}(I)$ licensing of those engaged in the insurance business, (2) control over the financial conditions of insurers, (3) control over forms of policies, (4) control over rates and premiums, (5) control over payment of private contract claims, and (6) control over business-getting methods. Another group of statutes, unconnected with the function of the insurance department, changes the rules for construction of insurance policies as laid down by the courts. Examples of this group are provisions that the agent is the agent of insurer for all purposes, that statements made in the application and policy are representations rather than warranties.

The purpose of this article is to collect and collate those statutes which exert an important influence on the business of Industrial insurance. Reliance has been placed on the various codes and compilations of statutes as the primary source of material; ${ }^{8}$ session laws have been checked from the date of the code or compilation to 1933. Where a particular statute is to be found in many jurisdictions, no exhaustive citation is attempted; rather, emphasis is placed on the atypical. After a discussion of the statutory definitions of Industrial insurance, the material presented consists of $(I)$ those statutes which exempt Industrial insurance from the requirements imposed on Ordinary insurance, (2) those which apply only to Industrial insurance, and (3) those applicable to both Ordinary and Industrial insurance, but which have a special significance in the field of Industrial insurance.

\section{Statutory Definttions of Industrial Insurance}

A statutory definition may create a legal institution, or it may represent an attempt to describe an existing economic or business institution in terms of its most important and most enduring features. Definitions of Industrial insurance are of the latter type. In many statutes the term "Industrial insurance" is used without defining it. ${ }^{\circ}$

${ }^{7}$ See table of contents in Patrerson, The Insurance Commissioner in the United States (1927).

8 The fragmentary nature of statutes on Industrial insurance as well as the inadequate indices of the session laws rendered more extended use of the session laws inadvisable.

${ }^{9}$ The term is found most often without definition in the blanket exemption of Industrial insurance from the requirement that enumerated provisions be included in the policy. Ariz. Rev. Code (Struckmeyer, 1928) \$1847; Neb. Comp. Stat. (1929) c. 44-602; Okza. Comp. LAws Ann. (1921) \$6737; S. D. Comp. Laws (1929) \$9346; Wash. Rev. Stat. (Remington, 1933) \$7230; Wyo. Laws 1931, c. $15, \$ 32$. 
Reliance is placed on current business usage to distinguish it from other forms of insurance. ${ }^{10}$ Where definition is attempted, Industrial insurance is generally described as consisting of small policies ${ }^{11}$ issued in consideration of weekly, ${ }^{12}$ or, less often, weekly or monthly, ${ }^{13}$ premiums, in contrast to Ordinary insurance where the premiums are payable annually, semi-annually, and quarterly. In Louisiana, Industrial insurance "must provide a weekly cash benefit for disability caused by sickness or accident"; 41 in other jurisdictions the inclusion of such a provision is optional. ${ }^{15}$ Precise statutory definition is difficult because Industrial insurance as a separate category is a creature of changing business practice, not of the law.

\section{Statutory Provisions Exempting Industrial Insurance from Requirements IMPOSED ON ORDINARY INSURANCE}

The view that Industrial insurance represents a distinct field which either does not require as much statutory regulation as Ordinary insurance or is not amenable to that type of regulation finds expression very often in the blanket exemption of Industrial insurance from general statutory regulations. ${ }^{16}$ The following sections indicate more particularly some of the requirements which have been made inapplicable to Industrial insurance.

\section{Capital Stock, Deposit, and Reserve Requirements}

Special statutory regulation of Industrial insurance companies intended to preserve their solvency has been relatively insignificant, due perhaps to the domination of this field by three companies whose stability has been unquestioned. ${ }^{17}$ Generally, the formation and control of these companies is governed by the same laws limiting those transacting Ordinary insurance. ${ }^{18}$ Special regulation has usually been for the purpose of relaxing such statutory requirements for incorporation as relate to capital

${ }^{10} \mathrm{D}$. C. CoDE. (I929) c. 7, $\$ 18 \mathrm{I}$ ("business commonly known as industrial insurance").

II GA. ANn, Code (Michie, I926) \$2502; LA. Gen. Stat. (I932) \$4II9; Md. Ann. Code (Bagby, 1924) art. 48A, \$98 (not exceeding \$1,000); Mo. Rev. Stat. (r919) \$6200 (up to \$500; N. Y. Cons. Laws (Cahill, 1930) c. 30, $\$ 83 \mathrm{~A}$ (b) (if premiums payable monthly, up to \$1000).

${ }^{10}$ ARk. Dig. Stat. (Crawford \& Moses, Supp. I927) \$6016e; Del. Laws I931, c. 52, \$24; ME. Rev. Stat. (1930) c. 60, $\$ 140 ;$ Mass. Ann. Laws (1933) c. $175, \$ \$ 140$, x45 (but see $\$ 146$ and $\$ 147$ where frequency' of payment is not mentioned); Mo. Rev. Stat. (I919) $\$ 6200$; N. H. Pub. Laws (I926) c. 273, 535; N. Y. Cons. LAws (Cahill, I930) c. $30 \$ 83 \mathrm{~A}$ (a) (regardless of the face value of the policy); R. I. GEN. LAWS (1923) 53800 .

${ }^{23}$ LA. GeN. Stat. (1932) $\$_{41}$ I 9 ; N. Y. Cons. LAws (Cahill, x930) c. $30, \$ 83 \mathrm{~A}$ (a) (if face value of policy is less than \$IOOO); VA. CODE (Michie, 1930) \$42x8 (a); W. VA. CODE (Michie, I932) \$3302; but see GA. ANN. Code (Michie, I926) \$2502, where frequency of payment is immaterial.

"LA. Gen. Stat. (I932) \$4IIg.

${ }^{25}$ GA. AnN. Code (Michie, I926) \$2502; Md. ANn. Code (Bagby, 1924) art. 48A, \$98.

${ }^{13}$ Ga. Ann. Code (Michie, 1926) \$2507; Ill. Rev. Stat. (Cahill, 1929) c. 73, \$380; Ind. Ann. Stat. (Burns, 1926) \$904r; LA. Gen. Stat. (I932) \$4124; OhIo GEN. Code (Page, r926) \$9425; S. D. CoMpP. Laws (1929) \$9346.

${ }^{17}$ TAYLOR, op. cit. supra note $\mathrm{x}$, at 15 . The Prudential, Metropolitan, and John Hancock companies hold 85 per cent of the Industrial insurance business.

${ }^{18}$ ARx. Dig. Stat. (Crawford \& Moses, Supp. 1927) §6016f; GA. ANn. Code (Michic, 1926) \$2427 (3); Kan. Rev. Stat. ANn. (Supp. 1933) c. 40-40I; LA. Gen. Stat. (1932) 54125. 
stock required 19 and the amount of deposit to be made with the commissioner of insurance. ${ }^{20}$ Also, in some states, by statute, valuation of Industrial policies may be based upon standard or sub-standard Industrial mortality tables rather than upon the American experience table of mortality ${ }^{21}$ which reflects a lower mortality rate. Encouragement for the local Industrial insurance company which would find it difficult to meet the higher reserve and deposit requirements is the probable explanation for these modifications. In the absence of a statute permitting such variations the commissioner may not depart from the rule laid down by statute for computing the minimum reserve to be maintained by the company. ${ }^{22}$

\section{Medical Examination}

In the general statutory regulations relating to life insurance there is commonly a provision requiring a medical examination of the life insured before the issuance of the policy. ${ }^{23}$ This requirement is very often made inapplicable to Industrial insurance policies ${ }^{24}$ or policies below a specified amount. ${ }^{25}$ Occasionally the exemption may combine both elements by providing that policies of Industrial insurance below a certain figure may be issued without a medical examination. ${ }^{20}$ A trend toward the elimination of the medical examination requirement in the issuance of the smaller Ordinary insurance policies is apparently destroying the non-medical basis as a distinctive characteristic of Industrial insurance. ${ }^{27}$

\section{Licensing of Agents}

In Ordinary insurance, once the policy is written, the agent becomes an insignificant factor in the relationship between the insurer and the insured. In Industrial insurance, on the contrary, the agent assumes paramount importance due to his function as collector of the weekly premiums and to his important influence over the insured. Practically all states provide that solicitors and agents of all types of insur-

${ }^{19}$ Ga. AnN. Code (Michie, I926) \$2505 (1); Kans. Laws Spec. Sess. I933, c. 72, \$1; LA. Gen. Stat. (1932) \$4126; Mo. Rev. Stat. (Igrg) \$6195; OkLA. Comp. Stat. ANn (Supp. I926) \$6908-2; Va. Code ANN. (Michie, I930) $\$ 4218$ (a).

${ }^{20}$ Ga. Ans. Code (Michie, 1926) $\$ \$ 2504,2505$ (I); La. Gen. Stat. (1932) \$4121; Mo. Ann. Code (Bagby, I924) art. 48A, \$20; Mo. Rev. Stat. (19r9) \$6r97; Orza. Comp. Stat. AnN. (Supp. 1926). $\$ 6908-3$; S. C. CODE (I932) \$7947; VA. CoDE ANN. (Michie, I930) \$4218a.

${ }^{21}$ ArIz. Rev. Code (Struckmeyer, I928) \$1787; N. J. Comp. Stat. (Cum. Supp. 1925) \$99-24 (commissioner may vary the standards of interest and mortality in the case of Industrial policies); N. Y. Cons. Laws (Cahill, I930) c. $30, \$ 84$ (6).

2 Patterson, op. cit. supra note 7 , at 197 .

${ }^{2}$ Ariz. Rev. Code (Struckmeyer, r928) \$r845; Wask. Rev. Stat. (Remington, r933) \$7228.

24 ArIz. Rev. COde (Struckmeyer, I928) \$1845; Ga. ANN. Code (Michie, 1926) \$2501 (1); Nen. Comp. StAт. (r929) c. 44-802.

${ }^{2}$ Miss. AnN. CODE (1930) $\$ 5158$ (\$2500); Nev. Comp. Laws (Hillyer, 1930) $\$ 3592$ (\$100); N. C. Code ANn. (Michic, I93I) $\$ 6460$ (\$5000); Okla. Laws 1931, c. 51, art. I (policies not exceeding \$10,000); Tex. Gen. Laws I933, c. 193, \$I (\$500).

${ }^{\Im}$ IoWA CODE (193I) $\$ 8671$ (Industrial policies in amount of $\$ 2000$ and less); MAss. ANN. Code (1933) c. $175, \$ 123$ (\$500 and less).

${ }^{3}$ Neb. CoMp. Stat. (1929) c. 44-802 (no medical examination for Industrial insurance policies), Neb. Laws I933 c. 76, § I (no medical examination for policies of $\$ 5000$ and less); Mo. Rev. STAT. (Minturn, Ann. Supp. 1927) 56193, and Mo. Laws 1929, 238; also OxLA. Comp. Laws ANn. (Supp. 1926) $\$ 6729$, and Okla. Laws $x 93$ I, c. 5r, art 1 . 
ance must be licensed by the commissioner of insurance; and this license may be revoked for cause. ${ }^{28}$ But in New York, agents soliciting applications for Industrial insurance need not procure a certificate of authority. ${ }^{29}$ In the early days of Industrial insurance, the agency turnover was so rapid it was considered advisable to exempt Industrial agents from the requirement of license so as not to impose an undue burden on the Industrial insurance company. This exemption is of no great consequence at the present time since practically all Industrial agents write Ordinary insurance and thus come within the scope of the licensing law. ${ }^{30}$

\section{Limitations on Expense}

A common criticism of Industrial insurance is the heavy expense incident to its administration and solicitation as compared to Ordinary insurance. ${ }^{31}$ More than a generation ago Justice Brandeis noted this fact and proposed comprehensive and radical legislation to remedy what he considered a serious situation. ${ }^{32}$ Yet Wisconsin, in imposing very detailed limitations on expenses to be incurred and requiring data on such expenses to be submitted to the insurance commissioner, specifically exempts Industrial insurance from the application of this act. ${ }^{33}$ Further examination as to the desirability of imposing such expense limitations on the Industrial insurance company ought to be undertaken. Perhaps the higher and less certain cost of administration in Industrial insurance may render a different and more flexible standard necessary, but difficulties in setting standards for limitation of expenses should not deny protection where the need has been found urgent. New York, recognizing to some extent the need for such legislation, has placed a limitation on the commission payable to Industrial insurance agents and supervisors. ${ }^{34}$

\section{Discount for Direct Payment}

One company has made considerable progress in eliminating the agent's collection function by allowing a ten per cent discount for direct payment to the district office. ${ }^{\mathbf{3 5}}$ As this refund might be regarded violative of the prohibition against rebating, special statutes have been passed to permit this reduction in premium payments. ${ }^{36}$ Similar

${ }^{20}$ D. C. COde (I929) c. 7, \$I80; IDAHo ANN. Code (I932) \$\$40-IOOI, 40-1004; ME. Rev. Stat. (1930) c. 60, §§I22, 123; TENN. CoDE (1932) \$\$6I40, 6I 45.

${ }^{0}$ N. Y. Cons. Laws (Cahill, 1930) c. 30, \$91 (3). Also D. C. Code (1929) c. 7, §I8I (license fee for solicitors of Industrial insurance is $\$ 2.00$ as compared to $\$ 5.00$ fee for solicitors of other forms of insurance); MD. ANN. CoDE (Bagby, I924) art. 48A, $\$ 103$ (Industrial insurance agents must furnish bond of not less than $\$ 50$ to company).

${ }^{\infty}$ This information was obtained from a letter of the Superintendent of Insurance of New York, George S. Van Shaick, to the Special Editor of this issue.

al Maclean, Life Insurance (1932) 359.

arandeis, Business a Profession (I933 ed.) 145, I63-169.

Wis. Stat. (1929) c. 206.27, 206.30; also N. Y. Cons. Laws (Cahill, 1930) c. 30, $\$ 97$ (9).

iN. Y. Cons. CODE (Cahill, r930) c. $30, \$ 97$ (ro) (55 per cent of the first year's premiums and 5 per cent of renewal fees are allowed the agent).

$\approx$ The Metropolitan Insurance Company provides for direct payment of premiums in the policy. See Acrerasan, op. cit. supra note 3 , at 167 .

${ }^{\infty}$ Del. Laws I931, c. 52, \$24; Fla. Rev. Stat. (1927) §6225; IdAho ANn. Code (r932) \$40-I Io7; ME. Rev. Stat. (1930) c. 6o, \$140; N. H. Pub. Laws (1926) c. 273, \$35; N. Y. Cons. Laws (Cahill, 1930) c. $30, \S 89 ;$ R. I. Gen. Laws (1923) $\$ 3800 ;$ W. VA. Code (Michie, I932) \$3302. 
legislation should be enacted in those jurisdictions where the legality of such refunds might be called into question. ${ }^{37}$

\section{Basis of Agent's Compensation}

The high lapse rate in Industrial insurance represents an economic waste which is a most disturbing problem to the Industrial insurance company. To counteract keen competition among agents and the resultant tendency to write insurance which is quickly lapsed, one of the bases of the compensation of the Industrial agent, long and widely used, is the net weekly increase in the size of the "debit," that is, the difference between the new premiums and the premiums on policies lapsed.88 Wisconsin forbids all commissions or compensation of any sort based upon the aggregate of policies written or paid for, but this statute does not apply to Industrial insurance. ${ }^{39}$ If it did, the cumulative system of compensation which places responsibility for lapses on the agent would be made illegal.

\section{Prizes and Bonuses}

That high pressure salesmanship is an important cause of the high lapse rate is recognized by insurance officials. ${ }^{40}$ Special prizes and bonuses offered agents increase the temptation to write business which the agent may have reason to believe will, be quickly lapsed. Several jurisdictions, prohibiting such bonuses, prizes, and awards limit the application of the statute to Ordinary insurance. ${ }^{41}$ This exemption seems unnecessary and undesirable, and might well be eliminated.

\section{Uniform or Standard Policy Requirements}

Legislative prescription of policy provisions constitutes a pointed recognition of the fact that the insurance policy is not a contract in which both parties bargain on an equal footing. This inequality may be attributed not only to the marked difference in their bargaining power but also to the inability of the purchaser of an insurance policy to discriminate between the good and the bad. ${ }^{42}$ The Industrial insurance policyholder is especially deserving of protection on both counts. Yet the blanket exemption of Industrial insurance is the rule rather than the exception in those statutes which enumerate provisions required in life insurance policies. ${ }^{43}$

The view that Industrial insurance should be given the widest latitude in its development is probably the explanation for these numerous exemptions. ${ }^{4 *}$ If this

\footnotetext{
${ }^{3}$ For a proposal to compel by statute a general adoption of such a discount, see Fuller, supra at p. 20.

${ }^{33}$ TAYZOR, Op. cit. supra note $\mathrm{I}$, at 122 et seq.: "Debit" refers both to the territory assigned the agent and the premiums which are to be collected within that area.

${ }^{30}$ N. Y. Cons. LAws (Cahill, 1930) c. 30, 597 (4), (9); Wis. Stat. (1929) c. 206.32.

${ }^{\infty}$ Acrerman, op. cit. supra note 3 , at 135 .

${ }^{a}$ N. Y. Cons. LAws (Cahill, r930) c. 30, \$97 (4) (9); W1s. StaT. (1929) c. 206.32.

2 Patterson, op. cit. supra note 7, at 244 .

${ }^{2}$ Del. Laws I931, c. 52 \$35; InD. Ans. Stat. (Burns, I926) $\$ 99036$, g041; N. Y. Cons. Laws (Cahill, I930) c. 30, \$IOI; PA. StAT. (Supp. I928) \$12490b-410.

cas Cf. the importance placed on the desirability of latitude for experimental development in group insurance in Hanft, Group Insurance: Its Legal Aspects, infra pp. 7r-73.
} 
be so, it would seem that the necessity for those exemptions has ceased and that the various statutory policy requirements should be reëxamined in order to determine whether their inclusion in the Industrial insurance policy is desirable. At the present time, as far as any statutory requirements are concerned, an unlimited variety of Industrial insurance policies may be offered those who are least able to exercise a discriminating judgment. The principal exemptions from uniform or standard policy requirements are discussed in the paragraphs following.

(a) Policy must have Application Attached

Generally, by statute, applications for insurance, when not attached to the policy, are not considered a part of the contract, and statements made therein may not in such case be introduced as evidence by the insurer in an action on the policy. ${ }^{4}$ Frequently, Industrial insurance is exempted from this requirement, ${ }^{45}$ presumably on the ground that the making of a photostatic copy of the application to be attached to the policy, which is the standard practice in Ordinary insurance, involves an undue expense in the case of small policies of Industrial insurance. This exemption is rendered less significant by the fact that the Industrial policy usually provides that it shall constitute the entire agreement of the parties. ${ }^{46}$ Such a stipulation prevents the introduction of the application as evidence by the insurer in an action on the policy.

(b) Requirement of Notice and Grace Period

A number of statutes exempt Industrial insurance from the requirement of notice to the insured as a condition precedent to forfeiture or cancellation of the policy for non-payment of premiums. ${ }^{47}$ Likewise, the Industrial insurance policy usually need not provide for a grace period. 48 Thus, as far as any statutory protection is concerned, the policy may be lapsed on failure to meet any weekly payment. The weekly visit by the Industrial agent makes oversight on the part of the insured, in making premium payment, very unlikely; and, for this reason, requirement of notice is superfluous. For the same reason, the tremendous expense involved in provision for such notice would seem highly disproportionate to the benefits derived by the Industrial policyholder. Normally the Industrial insurance policy does provide for a four-week grace period. ${ }^{49}$ In some jurisdictions, if such a grace period is not given, the company must give thirty days notice to the insured before lapsing.50

"Conn. Gen. Stat. (1930) \$4Igx; Del. Laws I93I, c. 52, \$48; D. C. Code (1929) c. 7, §183; LA. Gen. Stat. (1932) \$4II3; Me. Rev. Stat. (1930) c. 60, \$I47; Miss. Ann. Code (I930) \$5I74; Mo. Rev. Stat. (I919) \$6I84; N. H. Pub. Laws (1926) c. 277, §8; OkLA. Comp. Stat. (I921) §6728; TeX. Comp. STAT. (1928) $\$ 4732(3)$.

${ }^{*}$ ArIz. REv. COde (Struckmeyer, I928) §I849; Ill. Rev. Stat. (Cahill, I929) c. 73, \$375 (3); IND. Ann. Stat. (Burns, I926) $\$ 9036$ (3), 9041; Neb. Comp. Stat. (I929) c. 44-602 (3); PA. Stat. (Supp. 1928) §I2490b-410 (d); TenN. CODE (I932) §6086; Wask. Rev. Stat. (Remington, I933) §7231.

"Ackernan, op. cit. supra note 3 , at $166,175,182$.

${ }^{17}$ Kan. Rev. Stat. Ann. (Supp. I933) c. 40-410; N. Y. Cons. Laws (Cahill, 1930) c. 30, \$92; N. C. Ans. Code (Michie, I93I) $\$ 6465$. Although provision for notice is not generally included in the standard policy form, it is discussed here because of its connection with the grace period.

${ }^{40}$ N. Y. Cons. Laws (Cahill, 1930) c. 30, §IOr (1); S. D. CoMp. Laws (1929) $\$ \$ 9340$ (2), 9346.

¿Ackerman, op. cit. supra note 3, at 174,177 .

${ }^{20}$ Kans. Rev. Stat. AnN. (Supp. I933) 40-410; La. Gen. Stat. (I932) \$4132. 
(c) Requirement as to Incontestability and the Effect of Age Misstatement

The majority of states require that the Ordinary policy shall be incontestable after a stated period from date of issue except for non-payment of premiums. ${ }^{\text {"1 }}$ Similarly, it is required that the Ordinary policy contain a provision that in event of misstatement of age, the amount payable under the policy shall be such sum as could have been purchased at the true age by the premium actually paid. ${ }^{52}$ Although not required by statute, both provisions are to be found in practically all Industrial insurance policies. ${ }^{53}$

(d) Options in the Event of Default in Premium Payments

Generally, statutory provisions requiring that specified options be given the policyholder in the event of default in premium payments do not apply to Industrial insurance. ${ }^{54}$ But several states make provision for the Industrial policyholder. ${ }^{55}$ In Massachusetts, where the premium is not more than fifty cents weekly, the surrender value is payable in cash within sixty days after demand, which must be made not later than two years from the date of the lapse. To inform the policyholder that he still has a claim under the policy, notice must be sent to his last known address. ${ }^{\text {.0 }}$ After premium payments are made for three years on any policy of Industrial insurance in event of failure to make a subsequent payment the policy is automatically binding as extended term insurance for its face amount. ${ }^{57}$ Where premium payments have been made for five years, the policyholder is given the election of a paid-up policy or its value in cash.58 Although not required by statute, practically all Industrial policies contain non-forfeiture provisions. ${ }^{50}$

(e) Requirement of Distribution of Policy Dividends

Statutory provisions requiring the distribution of surplus at the end of a certain period are usually inapplicable to Industrial insurance. ${ }^{.0}$ Several states have made special provision for Industrial insurance, specifying when payment of surplus should begin and what form these payments should take. ${ }^{61}$ Massachusetts, for instance, provides that in Industrial policies, the annual surplus distributions shall begin not later than the end of the fifth policy year and may be applied to the payment of any

a Ind. Ann. Stat. (Burns, I926) $\$ \$ 9036$ (3), 9041; S. D. Comp. Laws (1929) $\$ 9313$.

E2 Ill. Rev. Stat. (Cahill, I929) c. 73, $\$ 375$ (4); S. D. Comp. Laws (1929) \$9314.

${ }^{23}$ Ackerman, op. cit. stipra note 3 , at $176,183,184$.

a Idafo Code (1932) \$40-1303 (8); Neb. Comp. Stat. (1929) c. 44-602 (9); N. J. Comp. Stat. (1910) $\$ 94$ (7), p. 2869; Ore. ANN. Code (1930) \$46-506 (h); PA. Stat. (Supp. 1928) \$12490b-410 (i); Utah Rev. Stat. ANN. (1933) \$43-3-24 (8).

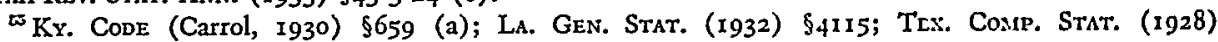
$\$ 4732$ (7); W. VA. CODE (Michie, I932) $\$ 3343$.

${ }^{63}$ Mass. Ans. Code (1933) c. $175, \$ 145$.

"Id. $\$ 146$

${ }^{\text {to } I d . ~} \$ 747$.

${ }^{*}$ For a discussion of the non-forfeiture provision in Industrial insurance, see Fuller, supra at p. 25.

${ }^{\infty}$ Ill. Rev. Stat. (Cahill, 1929) c. $73, \$ 375$ (5) a; IND. ANN. Stat. (Burns, 1926) $\$ \$ 9036$ (6), 904I; Minn. Stat. (Mason, 1927) §\$3394, 3395; Neb. Comp. Stat. (1929) c. 44-602 (7); N. J. Comp. Stat. (rgro) $\$ \$ 94$ (6), 99, p. 2869; N. D. Comp. Laws Ans. (1913) $\$ \$ 4882,4883$; Ore. Ann. Code (1930) $\$ 46-506$ (c); PA. StAT. (Supp. 1928) \$I2490b-4I0 (f).

2 LA. Gen. Stat. (1932) \$4I04; MD. Ann. Code (Bagby, r924) art. 48A, §89; Tenn. Code (1932) $\$ 6208 ; \mathrm{W}$. VA. CODE (Michie, 1932) \$3335. 
premiums or at the option of the holder of the policy be paid in cash. ${ }^{62}$ In other jurisdictions, where the surplus has not been paid in cash nor applied to premium payments, it is payable at the maturity of the policy. ${ }^{63}$ Policy provisions as to the distribution of surplus vary. ${ }^{64}$

\section{Administrative Control of the Policy Form}

Generally the policy form must be approved by the insurance commissioner before it may be sold by the company. Numerous statutes, however, require no submission of the Industrial insurance policy form to the insurance commissioner for approval where such a requirement is imposed in the case of Ordinary insurance. ${ }^{65}$ Since statutory restrictions and required provisions do not extend to Industrial insurance, it is perhaps felt that review by the insurance commissioner would serve no useful purpose. Such a view disregards the extra-legal pressure that may be exerted by the commissioner in asking that a particularly obnoxious provision be eliminated or that a desirable one be included. ${ }^{66}$

\section{Statutory Provisions Affecting Abuses and Dangers Peculiar to Industrial Insurance}

\section{Provisions Intended to Eliminate Sharp Practices by Undertakers}

Industrial insurance is primarily taken out to provide for funeral expenses and other expenditures incident to the last illness. Certain abuses, which have grown out of this special purpose of Industrial insurance, have been prohibited by statute. The undertaker, informed of the face value of the policy by an agent, often adjusts the cost of the funeral to the amount of the policy. ${ }^{67}$ To prevent such collusion, a Georgia statute makes it a misdemeanor for anyone engaged in the Industrial insurance business to receive any commissions from an undertaker. ${ }^{68}$

It has been felt desirable to give the beneficiaries of the policy the opportunity to purchase funeral services with the advantages of competition. Thus, Ohio prohibits "the payment of the proceeds of a policy to a designated undertaker so as to deprive

${ }^{\infty}$ Mass. ANn. Code (1933) c. $175, \$ 140$.

${ }^{\infty}$ LA. Gen. Stat. (1932) $\$ 4104$ (at the option of the company); W. VA. CODE (Michie, 1932) $\$ 3335$.

andustrial insurance was originally written on a non-participation basis. But at present all the large Industrial insurance companies provide for participation in the surplus by the policyholder. See AckerMaN, op. cit. supra note 3 , at $167,173,177$.

IDako ANN. Code (I932) \$40-1303; Ill. Rev. Stat. (Cahill, I929) c. 73, $\$ \$ 378,380$; IND. ANN. Stat. (Burns, 1926) \$\$9039, 904I; Minn. Stat. (Mason, I927) \$\$3408, 3410; Neb. Comp. Stat. c. 44-8or; Oho Gen. ANn. Code (Page, 1926) \$\$9423, 9425; OkLA. Comp. Stat. Ann. (I921) \$\$6734, 6737; S. D. CoMp. Laws (1929) §\$9342, 9346.

is Patterson, op. cit. supra note 7, at 284-285. The Superintendent of Insurance of New York, George S. Van Shaick, writes: "While the law of this state exempts industrial insurance from the standard provisions, nevertheless the policies must be filed with the Department and approved by the Superintendent of Insurance and it has been the policy of this department to require industrial policies to have all the standard provisions in the policies wherever applicable and to the extent that industrial insurance fits into the standard provisions picture." (From a letter to the Special Editor of this issue).

${ }^{6}$ TAYLoR, op. cit. supra note $\mathrm{I}$, at 81. See the section, "The Undertaker and the Facility of Payment Clause," in Fuller, supra at p. 38.

${ }^{\infty} \mathrm{Ga}$. Laws 1933, 186. 
the representative of the deceased from purchasing in the open market." ${ }^{\circ 0}$ Perhaps for the same reason a number of jurisdictions provide that funeral benefits must be paid in cash rather than in services. ${ }^{70}$

\section{Provisions against Misrepresentation and Twisting}

Misrepresentations by the agent in order to induce the insured to lapse the policy in one company and to repurchase in another is an especially serious problem in the field of Industrial insurance due to keen competition and to the important influence of the agent over the insured. ${ }^{71}$ Such tactics are under ban in every jurisdiction. ${ }^{72}$ Maryland gives recognition to the peculiar significance of "twisting" in the Industrial field by providing that "every debit shall be deemed wholly the property of the company in whose name such policies, contracts, or obligations were written or assumed" and no agent may switch any part of a debit without the consent of the company in writing. ${ }^{73}$ Several jurisdictions make it a misdemeanor to make or aid anyone in making a fraudulent statement in an application for Industrial insurance. ${ }^{74}$

\section{Statutes Relating to the "Sound Health" Clause}

A most prolific source of litigation in the Industrial policy is the "sound health" clause. Typically it provides that "if the insured is not in sound health on the date the policy was issued, the company may declare the policy void and its liability be limited to the return of premiums paid on the policy."75 "The "sound health" clause coupled with the non-medical nature of Industrial insurance results in a policy which may offer illusory protection to the insured until the contestable period has elapsed. To counteract a strict construction of statements by the insured as warranties, statutes generally provide that oral or written misrepresentations made in the negotiation of a policy shall not avoid the policy unless made with intent to deceive or unless material. $^{76}$ Expressly $^{77}$ or by judicial decision ${ }^{78}$ these statutes have been made referable only to statements in the application and thus have not affected the construction of the "sound health" clause which usually appears in the body of the policy.

It has been felt that the risk of death from undiscovered disease should be assumed by the insurer, not the policyholder. ${ }^{79}$ Congress, in its recent enactments on Indus-

${ }^{\infty}$ Minn. Laws 1933, c. 73, \$I; Oho GEN. Code (Page, I926) $\$ 666$.

${ }^{0}$ Kans. Laws Spec. Sess. 1933, c. 72, p. 89; Ky. Stat. (Carrol, Supp. I933) \$rg9a-11; Minn. Laws I933, c. 73, 51; N. D. Laws, 1931, c. 160 .

${ }^{2}$ TAYLOR, op. cit. supra note 1 , at 148 .

${ }^{72}$ S. D. CoMp. LAWs (I929) §9I83; Va. Acts I932, c. 250.

${ }^{73}$ MD. Ann. Code (Bagby, I924) art. 48A, \$95; also see Tenn. Code (I932) $\$ 6443$.

74 Tenn. COde (I932) \$6446; Idaho ANN. CODE (r932) \$40-1315; Nev. Conp. Laws (Hillyer, 1932) \$3592; also PA. STAT. (Supp. I928) \$I2490b-4I4.

TCKerman, op. cit. supra note 3, at 183 .

"VANCE, The LAW of Insurance (2d. ed. I930) 394.

$\pi$ Ala. Code (I928) \$8364; Mo. AnN. Code (Bagby, I924) art. 48A, \$87; VA. Code (1930) \$4220; Wash. Rev. Star. (Remington, I933) \$7078.

${ }^{78}$ Barker v. Metro. Life Ins. Co., I 88 Mass. 542, 74 N. E. 945 (1905); Contra Metro. Life Ins. Co. v. Goodman, ro Ala. App. 446, 65 So. 449 (1914).

${ }^{7}$ Hearing before the Subcommittee, supra note 6 at Iro. 
trial insurance for the District of Columbia, makes good faith the criterion. The policy is not to be held invalid because of unsound health unless the insurer proves that the insured had knowledge of, or reason to know, the facts on which the defense is based, or that the insurance was procured in bad faith or with intent to defraud the company. No policy of Industrial insurance is contestable upon any ground relating to health after two years from its date of issue. ${ }^{80}$

Not infrequently, false statements as to the health of the insured are inserted by the agent in the application where the correct information has been given him. By statute, in all matters relating to the application for insurance and the policy, the solicitor is the agent of the insured. ${ }^{81}$ Where the insured has acted in good faith, the company is generally estopped from asserting the falsity of the statements. ${ }^{82}$ Several states have passed statutes designed to force the company to accept greater responsibility for the acts of its agents. Thus, where a policy is issued without medical examination, statements made in the applications as to age, physical condition, and family history of the insured, are binding on the company, in the absence of fraud on the part of the insured. ${ }^{83}$ Louisiana has gone still further providing that whenever the agent has had an opportunity to ascertain the true condition of the health, habits or occupation of the insured and has certified the desirability of the risk to the company, the knowledge acquired or which could have been acquired by the agent with due diligence in securing the application is imputed to the company. ${ }^{84}$ This section is applicable even where the insured has been guilty of fraud..$^{85}$

\section{Facility of Payment Clause}

All Industrial policies contain the so-called facility of payment clause which gives the company the privilege of paying the proceeds of the policy to anyone appearing "equitably entitled thereto."86 Despite the paternalistic nature of the power which this provision gives the insurance company over the right of the insured to dispose of the proceeds of the policy, it has been interpreted most liberally by the courts. ${ }^{87}$

The justification for the clause is usually found in the fact that it speeds up the settlement of claims and makes unnecessary the issuance of letters of administration

${ }^{60}$ Public, No. 269, 73d Cong., Ist Sess., $\$ \$ 2,3$ (1934).

${ }^{61}$ Del. Laws I931, c. 52, \$42; LA. GeN. Stat. (1932) $\$ \$ 4075,4096 ;$ N. H. Pub. Laws (1926) c. 277, §6; N. M. Ann. Stat. (1929) \$7I-I4I; N. C. Code (Michie, I93I) \$6465; Ore. Ann. Code (1930) $\$ 46-515$; Tenn. Code (1932) \$6087; W. VA. Code (Michie, 1932) \$3410.

Eelouche v. Metropolitan Life Ins. Co., 69 N. H. 587, 45 Atl. 414 (1899); Temmink v. Metropolitan Life Ins. Co., 72 Mich. 388, 40 N. W. 469 (1889).

${ }^{6}$ Aduz. Rev. Code (Struckmeyer, I928) §1849; Mass. ANn. Laws (1933) c. I75, \$124; Neb. Comp. STAT. (1929) c. $44-802$ (see Rev. Stat. 1913, $\$ 3256$ for correct wording of statute); N. C. CodE (Michie, (I93I) \$6460; OkLa. Comp. Stat. (I921) §6728; Wash. Rev. Stat. (Remington, I933) §723I. But see Carroll v. Metropolitan Life Ins. Co., 258 Mass. 249, I54 N. E. 757 (I927), holding that where a policy never issued as an obligation because issued in reliance on statement that insured was in "sound health," this section is not applicable.

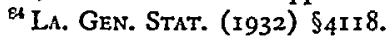

$\approx$ Williams v. Unity Industrial Life Ins. Co., I4 La. App. 680, 130 So. 561 (I930).

${ }^{6}$ Ackerman, op. cit. supra note 3, at 182 . For a discussion of the legal effects of this clause and of the practices of the companies in administering it, see Fuller, supra at p. 29.

${ }^{87}$ Watson v. Pilgrim etc. Ins. Co., 47 Ga. App. Rep. 581, I7I S. E. 226 (1933). 
where the beneficiary predeceases the insured or cannot be found. The same purpose explains a Maryland statute which provides that where one dies leaving no assets or property other than life insurance in an amount not exceeding $\$ 150.00$, the company may pay the proceeds of the policy to those entitled without the necessity of the grant of letters testamentary or letters of administration. ${ }^{88}$

Evaluation of the facility of payment has evoked extremes in praise and criticism. ${ }^{89}$ Congress, yielding to the critics of the facility of payment clause, has limited its use in the District of Columbia. The company may still pay to any claimant permitted by the policy, if the beneficiary does not present his claim in the proper form within fifteen days after the death of the insured. But a person designated in writing as one to whom the insured desires payment made, even though not formally designated as beneficiary, is regarded as such for the purposes of this section. ${ }^{90}$

\section{Assignability}

An effective assignment of the proceeds of the Industrial policy would defeat the company's option under the facility of payment clause. ${ }^{91}$ To prevent this and to avoid the legal complications incident to assignment, the Industrial insurance policy uniformly provides that any assignment or pledge of the policy is void. ${ }^{92}$ The right of the company to impose such a limitation on the beneficiary is recognized by statute. ${ }^{93}$ But Congress has provided that the Industrial insurance policy may be assigned; and on notice of the assignment the company is bound to pay the proceeds of the policy to the assignee. ${ }^{94}$

This review of statutes relating to Industrial insurance permits of several observations.

Industrial insurance has often been excepted from the requirements applicable to Ordinary insurance where the wisdom of such exceptions seemed doubtful. In many instances the companies have voluntarily given the policyholder the benefit of such provisions not required by statute.

To what extent business practice should be enforced and supplemented by legislation is the problem presented in the field of Industrial insurance. In working out its solution, consideration must be taken of the smaller Industrial insurance companies which may not be so ready to liberalize their contracts and methods as the larger companies have done. Also, it may be questioned whether reliance upon voluntary

\footnotetext{
${ }^{8}$ MD. ANn. Code (Supp. I929) art. $48 \mathrm{~A}, \$ 103 \frac{1 / 2}{}$.

${ }^{\circ}$ For approval of clause, sec Hearing before the Subcommittee, supra note 6, at 94 . For criticism, see Taylor, op. cit. supra note $\mathrm{I}$, at $80-84$.

${ }^{\text {s0 }}$ Public, No. 269, 73d Cong., Ist Sess., \$5 (r934).

${ }^{91}$ Doubt whether the provision prohibiting assignment has any significant legal effect is raised in Fuller, supra at p. 39.

${ }^{2}$ Ackerman, op. cit. supra note 3 , at 167.

$\$$ Kans. Laws 1933, c. 204, p. 304; Miss. ANn. Code (1930) \$5172; OrE. ANn. Code (1930) \$46-517.

Public, No. 269, 73d Cong., Ist Sess., \$4 (I934).
} 
change in business practice is an effective method of bringing about desired reforms where the interests of the insured and the company are not in strict harmony.

Abuses which have cropped up in Industrial insurance have received scant statutory recognition. Enactments have been few and fragmentary. However, the last Congress has made several important modifications in provisions characteristic of the Industrial insurance policy. Favorable experience with these changes would doubtless furnish a strong impetus to further statutory regulation of Industrial insurance. 